\title{
Editorial
}

\section{Big food}

Journal of Public Health Policy (20I2) 33, 285-286. doi:IO.I057/jphp.20I2.25

I first encountered Marion Nestle in the late I990s when I edited Public Health Reports, the scientific journal of the US Public Health Service. We published a provocative piece of hers about the marketing by Proctor and Gamble of Olestra, a zero calorie fat substitute. Marion taught me a great deal about how the food industry markets its products that are tasty, convenient, and relatively inexpensive. It markets intensively to children and continues to do so long after overeating and obesity have been shown to have deadly health consequences. Sound familiar? Perhaps like the tobacco industry.

In 2003, I invited Marion to Public Health Grand Rounds to describe the obesity epidemic to my public health students at Tufts Medical School. To follow Marion, I invited Richard Daynard from Northeastern Law School, who had litigated extensively against the tobacco industry. Dick carefully noted the differences between tobacco, which has no healthy use, and food. But he suggested that the anti-health behavior of the two industries might be similar: continuing to market products in a way that certainly harmed health.

When the public health faculty at Tufts and the law faculty at Northeastern joined forces to establish the Public Health Advocacy Institute, one of our first projects was Legal Approaches to the Obesity Epidemic $^{1}$, a symposium published in the Journal of Public Health Policy, in 2004. It attracted a great deal of attention and JPHP became a favorite place to publish research on obesity.

But I was not entirely pleased, because although the research was usually methodologically sound, it often missed Marion's point and the focus of the PHAI symposium. Most submissions concentrated on individual behavior and personal responsibility. In 20I0, I asked Marion, who was on the JPHP editorial board to join me in writing an Editorial: 'Obesity as collateral damage: a call for papers on the Obesity Epidemic'. ${ }^{2}$ We had 'come to believe that research studies concentrating on personal behavior and responsibility as causes of the obesity epidemic do little but offer cover to an industry seeking to downplay its own 
responsibility'. We urged 'authors to submit articles that consider how to understand and change the behavior of the food industry'.

Imagine our pleasure in learning that starting this June, PLoS Medicine will publish a series of articles exploring the food industry's involvement in health with Marion Nestle as a guest editor. To PLoS Medicine, we say bravo!

\section{References}

I. Journal of Public Health Policy (2004) Special section: Legal approaches to the obesity epidemic. $25(3 \& 4): 346-434$.

2. Robbins, A. and Nestle, M. (20I I) Obesity as collateral damage: A call for papers on the Obesity Epidemic. Journal of Public Health Policy 32(2): I43-I 45.

Anthony Robbins, M.D., M.P.A. Co-Editor 